\title{
Anacardium Occidentale and Jatropha Curcas Seeds' Alkaloids: Their Feeding Inhibitory and Growth Retardatory Potentials on Rhyzopertha Dominica
}

\section{Valentine Chi Mbatchou* and Eugene Owusu Asante}

Department of Applied Chemistry and Biochemistry, University for Development Studies, P. O. Box 24, Navrongo, Ghana. *Corresponding author

Received: 10 Oct 2020; Received in revised form: 10 Nov 2020; Accepted: 11 Nov 2020; Available online: 17 Nov 2020

\begin{abstract}
The damaging effect of Rhyzopertha dominica larvae and adult insects on the nutritive content and economic value of Zea mais seeds, and the cytotoxic nature of most phyto-alkaloids prompted this research work to be carried out. A. occidentale and J. curcas seeds' alkaloids were extracted and experimented for feeding inhibition and growth retardation on callow and mature adult $R$. dominica (Lesser grain borer) using maize seeds. Feeding inhibition for A. occidentale and J. curcas seeds' alkaloids on adult insects were 39.40\%, $49.88 \%, 81.37 \%, 100 \%, 47.48 \%, 55.12 \%, 93.31 \%, 100 \%$ respectively at $50 \mu \mathrm{g} / \mathrm{mL}, 150 \mu \mathrm{g} / \mathrm{mL}, 300 \mu \mathrm{g} / \mathrm{mL}$ and $400 \mu \mathrm{g} / \mathrm{mL}$ concentrations. Alkaloids from Jatropha curcas seeds demonstrated higher feeding inhibitory potentials than alkaloids from Anacardium occidentale seeds. Relative Growth Rates (RGR) of callow and mature R. dominica were retarded by A. occidentale and J. curcas seeds' alkaloid treatments. The feeding inhibitory potentials of $A$. occidentale and J. curcas seeds' alkaloids at $400 \mu \mathrm{g} / \mathrm{mL}$ concentration on both the callow and mature adult insects were translated to growth retardation of the insects when compared to maize seeds without alkaloid treatment (controls) fed by the insects. Relative Consumption Rates (RCR) of maize by callow and mature $R$. dominica were also reduced for maize seeds treated with alkaloids, indicating growth is a function of consumption. Thus alkaloids from Anacardium occidentale and Jatropha curcas seeds demonstrated feeding inhibitory and growth retardatory potentials on callow and mature adult $R$. dominica.
\end{abstract}

Keywords-Alkaloids, Anacardium occidentale, Consumption, Extraction, Feeding Inhibition, Growth, Jatropha curcas, Rhyzopertha dominica.

\section{INTRODUCTION}

\subsection{Rhyzopertha dominica and its feeding behavior}

Rhyzopertha dominica, also known as lesser or stored grain borer is in a monotypic genus of beetle, Rhyzopertha in the Bostrichidae family. It is a black-brown, slim, cylindrical, small insect of three millimeters length with shape similar to a bullet. Its head is attached to its thorax by a rounded neck shield covered with pits that get smaller toward the posterior end. A ten-segmented antenna is clubbed with last three segments forming a loose club. Each female lays up to five-

ISSN: $2456-1878$

https://dx.doi.org/10.22161/ijeab.56.6 hundred eggs either on kernels of grain or loosely in frass produced by the insects. Egg development takes five days at $36{ }^{\circ} \mathrm{C}$ and hatches into a larva which is white in color and cshaped. Larval development often takes twenty seven to thirty one days at $28{ }^{\circ} \mathrm{C}$ and forty six days at $25{ }^{\circ} \mathrm{C}$ respectively. Pupation takes approximately five to six days at $28{ }^{\circ} \mathrm{C}$ and eight days at $25^{\circ} \mathrm{C}$ respectively in an enlarged cell where the larval feeding tube ends, and the adult insect can live up to two hundred and forty days (Toews et al., 2006; Koehler et al., 2011; Mason, 2003). 
Infestation of grains by Rhyzopertha dominica larvae and adults originate from either residual population inside storage structures or immigration from outside sources, and insects have been shown to enter grain silos and other storages through vents and poorly sealed silo bases (Jia et al., 2008). Both the larvae and mature adult insects are voracious feeders that cause severe damage to chick peas, dried potatoes, herbs, wood, wheat, maize, rice, millet, peanuts, cocoa beans as well as processed products such as macaroni, tobacco and dried spices (Toews et al., 2006; Doug, 2009). They feed on the endosperm of grains by chewing their way through the bran layer, reducing grains to shells of bran, leaving behind large amounts of flour, tunnels, irregular shaped holes, and a sweet odor in grains as signs of infestation. Interestingly, the sweet odor produced by male Rhyzopertha dominica contains pheromones which have shown effectiveness as lures for use in insect traps. On a contrary, the larvae and adult insects do not infest standing grain and can survive outside the grain environment on seeds and acorns of other plants (Koehler $e t$ al., 2011; Doug, 2009).

\subsection{Anacardium occidentale}

Anacardium occidentale (Cashew) plant, a member of the Anacardiaceae family is a small tree having coriaceous leaves, polygamous flowers, with five petals and nine stamens. Fruits are fleshy, dark yellow or orange coloured (Ghodgate et al., 2013). Cashew nut shell, a honeycomb structure contains a natural resin, cashew nut shell liquid (CNSL) which is used as a raw material to develop drugs, antioxidants, fungicides etc., and for treatment of wood against termites. Medicinal properties of phytochemicals present in CNSL have been reported, and include cytotoxic activity against several tumor lines, anti-diabetic, anti-inflammatory and analgesic effects (Kanan et al., 2009). Cashew nut seeds are ground into paste to treat snake bites. Fruits, stem-bark and leaves have antifungal, antipyretic and antidiarrheal applications. They are used to treat sores and rashes. Leaf extracts have demonstrated growth inhibition against several species of bacteria and fungi ( Azam-Ali and Judge, 2004; Akash et al., 2009).

\subsection{Jatropha curcas}

Jatropha curcas plant, a member of the Euphorbiaceae family is a small drought resistant tropical tree or shrub which exudes whitish coloured, watery latex when cut. Normally, it grows between three and five meters high, but can attain a height of up to eight or ten meters under favorable conditions. It has large green to pale-green leaves which are alternate with a spiral phyllotaxis. Petiole length ranges between $6-23 \mathrm{~mm}$, and flowers are formed terminally and individually, with female flowers usually slightly larger and occur in the hot seasons. The plant is often used for fences or as hedges by locals especially farmers because it is not fed on by most animals and insects. Its latex contains an alkaloid known as "Jatrophine" which is believed to have anti-cancerous properties. It is applied externally as treatment for skin diseases, rheumatism, and sores on domestic livestock. Tender twigs of the plant are used for cleaning teeth, while juice of the leaves is externally applied against piles (Gupta $e t$ al., 2011). Its roots are used as an antidote for snake-bites. Seeds of this plant have been used traditionally to treat ailments like burns, convulsions, fever and inflammation. Seed oil is used externally for the treatment of sciatica, dropsy and paralysis. It has a strong purgative action, and has been reported to be a remedy for syphilis. Also, seed oil is known to be useful as an insecticide, for soap production and as a fuel substitute to produce biodiesel via transesterification.Explored chemical constituents of Jatropha curcas includes diterpenes, triterpenes, lignanes, coumarines, flavonoids, phytosterols (Demissie et al., 2013; Prasad et al., 2012; Ikbal, 2009).

\section{MATERIALS AND METHODS}

\subsection{Sample collection and authentication}

Fruits of Anacardium occidentale and Jatropha curcas were randomly harvested from trees in Kintampo and Navrongo respectively in the Brong Ahafo and Upper East Regions of Ghana. Plants were authenticated at the Department of Applied Biology, University for Development Studies, Ghana.

\subsection{Preparation of plants' seed samples}

Fruits of the plants were dried under shade for about a week at $25{ }^{\circ} \mathrm{C}$. Shells were removed and seed contents were dried under shade for 72 hours, and then ground into fine powder using a blender. The powders were stored in containers and later subjected to alkaloid extraction process.

\subsection{Alkaloid extraction}

Powdered seeds $(50 \mathrm{~g})$ of Anacardium occidentale and Jatropha curcas were separately soaked in $200 \mathrm{~mL} 95 \%$ ethanol solvent for three days and then filtered. Residues obtained were mixed with $1 \mathrm{M} \mathrm{HCl}$ and allowed to stand for 1 hour and then filtered. Ethanol solvent was evaporated from crude extracts in a water bath at $45^{\circ} \mathrm{C}$ leaving the concentrates. Concentrates were combined with $\mathrm{HCl}$ filtrates and mixed 
with excess dilute $1 \mathrm{M} \mathrm{HCl}$. Acid mixtures were basified by adding equal amounts of dilute $5 \mathrm{M} \mathrm{Na}_{2} \mathrm{CO}_{3}$ until swirls of white precipitates which were alkaloids clouded the solution. Next, an equal volume of $n$-hexane solvent was added to the mixture, poured in to a separating funnel and shaken. It was then allowed to stand overnight for the separation to take place. This step was repeated twice to get as much alkaloids as possible into the $\mathrm{n}$-hexane solvent. When the separation was over, the n-hexane solvent was evaporated in a water bath leaving the concentrated alkaloids.

\subsection{Test for crude alkaloids}

Few drops of Wagner's reagent were added to $1 \mathrm{~mL}$ solution of alkaloids, and brownish red precipitates indicated the presence of alkaloids.

\subsection{Insect rearing}

Ryzopertha. dominica insects (Callow adults of 21 days old and mature adults of 26 days old) reared in aerated containers at an average temperature of $32^{\circ} \mathrm{C}$ and relative humidity of $75 \%$, in light and dark conditions of 12:12 hours daily, and fed with maize grains at Savannah Agricultural Research Institute (SARI), Nyankpala in the Northern Region of Ghana were used for the experiment.

\subsection{Feeding inhibition test}

$R$. dominica insects were kept in aerated containers with each container having 6 insects. Containers with distilled water treated maize grains served as controls (three each for callow and mature adult insects), while those with alkaloids treated maize grains in distilled water solvent served as treatments. Alkaloids were tested in four different concentrations (50, 150,300 and $400 \mu \mathrm{g} / \mathrm{mL}$ ) on callow and mature adult insects, with each concentration in triplicate. Maize grains were soaked in these concentrations for 20 seconds and dried under shade for 24 hours. Insects in treatment containers fed on alkaloids treated maize while those in controls fed on distilled water treated maize. Weights of food consumed within 24 hours were recorded for six days, and the formula below was used to estimate feeding inhibition index of alkaloid extracts:

- $\quad$ Feeding Inhibition Index $($ FII $)=\frac{C-T}{C+T} \times 100$, where;

$\mathrm{C}=$ amount of distilled water treated maize grains eaten

$\mathrm{T}=$ amount of crude alkaloids treated maize grains eaten

Relative consumption rate was calculated as weight of food eaten divided by initial weight of insect.

- $\quad$ Relative Consumption Rate $=\frac{W c}{W}$, where;
$\mathrm{Wc}=$ weight of maize grains eaten.

$\mathrm{W}=$ weight of insect at the beginning of the experiment.

Relative growth rate was calculated as the difference in weight of the insects between the last day and initial day divided by the initial weight of the insect $R$. dominica.

- $\quad$ Relative Growth Rate $(\mathrm{RGR})=\frac{A-B}{B}$, where;

$A=$ weight of live insects on $6^{\text {th }}$ day

$\mathrm{B}=$ initial weight of insects.

\section{RESULTS}

Table 1: Results for presence and \% yield of alkaloids

\begin{tabular}{|c|c|c|}
\hline Seed Alkaloids & Inferences & \% yield \\
\hline A. occidentale & + & 10.34 \\
\hline J. curcas & + & 13.23 \\
\hline
\end{tabular}

Key: $(+)=$ present: $(-)=$ absent

Table 2: Feeding inhibitory indices of A. occidentale seed alkaloids on mature and callow adult $R$. dominica

\begin{tabular}{|c|c|c|c|}
\hline \multirow{2}{*}{$\begin{array}{l}\text { Concentration } \\
\quad(\mu \mathrm{g} / \mathrm{mL})\end{array}$} & \multicolumn{2}{|c|}{$\%$ FII } & \multirow{2}{*}{$\begin{array}{l}\text { Average } \\
\% \text { FII }\end{array}$} \\
\hline & $\begin{array}{c}\text { Mature } \\
\text { adults }\end{array}$ & $\begin{array}{c}\text { Callow } \\
\text { adults }\end{array}$ & \\
\hline 50 & 7.83 & 70.97 & 39.40 \\
\hline 150 & 16.99 & 82.76 & 49.88 \\
\hline 300 & 62.73 & 100.00 & 81.37 \\
\hline 400 & 100.00 & 100.00 & 100.00 \\
\hline
\end{tabular}

Key: FII = Feeding Inhibitory Indices (Expresses feeding inhibition potential)

Table 3: Feeding inhibitory indices of J. curcas seed alkaloids on mature and callow adult $R$. dominica

\begin{tabular}{|c|c|c|c|}
\hline \multirow{2}{*}{$\begin{array}{c}\text { Concentration } \\
(\mu \mathrm{g} / \mathrm{mL})\end{array}$} & \multicolumn{2}{|c|}{$\%$ FII } & \multirow{2}{*}{$\begin{array}{l}\text { Average } \\
\% \text { FII }\end{array}$} \\
\hline & $\begin{array}{l}\text { Mature } \\
\text { adults }\end{array}$ & $\begin{array}{l}\text { Callow } \\
\text { adults }\end{array}$ & \\
\hline 50 & 37.88 & $\begin{array}{l}56.98 \\
\end{array}$ & 47.43 \\
\hline 150 & 47.60 & 62.63 & 55.12 \\
\hline 300 & 86.62 & 100.00 & 93.31 \\
\hline 400 & 100.00 & 100.00 & 100.00 \\
\hline
\end{tabular}

Key: FII = Feeding Inhibitory Index (Expresses feeding inhibition potential) 
International Journal of Environment, Agriculture and Biotechnology, 5(6)

Nov-Dec, 2020 / Available: https://ijeab.com/

Table 4: Effects of A. occidentale and J. cucas seed alkaloids on Relative Growth and Consumption Rates of R. dominica at $400 \mu \mathrm{g} / \mathrm{mL}$

\begin{tabular}{|c|c|l|c|c|}
\hline \multirow{2}{*}{ Parameter } & \multicolumn{2}{|c|}{ J. curcas } & \multicolumn{2}{c|}{ A. occidentale } \\
\cline { 2 - 5 } & $\begin{array}{l}\text { Mature } \\
\text { adults }\end{array}$ & $\begin{array}{l}\text { Callow } \\
\text { adults }\end{array}$ & $\begin{array}{l}\text { Mature } \\
\text { adults }\end{array}$ & $\begin{array}{l}\text { Callow } \\
\text { adults }\end{array}$ \\
\hline $\begin{array}{l}\text { Control } \\
\text { (RGR) }\end{array}$ & 0.46 & 0.21 & 0.44 & 0.26 \\
\hline RGR & -0.28 & -0.13 & -0.18 & -0.13 \\
\hline $\begin{array}{l}\text { Control } \\
\text { (RCR) }\end{array}$ & 48.26 & 88.71 & 24.43 & 72.14 \\
\hline RCR & 24.95 & 70.70 & 14.29 & 44.20 \\
\hline
\end{tabular}

Key: RGR= Relative Growth Rate, $\mathrm{RCG}=$ Relative

Consumption Rate

\section{DISCUSSION}

Alkaloids were found present in the seeds of Anacardium occidentale and Jatropha curcas respectively (table 1). Feeding inhibitory potentials (\% FII) for A. occidentale and $J$. curcas seeds' alkaloids on callow and mature adult $R$. dominica were concentration dependent, and increased as alkaloids' concentrations were increased. The alkaloids exhibited $100 \%$ feeding inhibition on the callow and mature adult insects at $300 \mu \mathrm{g} / \mathrm{mL}$ and $400 \mu \mathrm{g} / \mathrm{mL}$ respectively, implying the alkaloids were more effective feeding inhibitors on the callow adult insects than mature adults (tables 2 and 3 ). This is in line with documented reports that the mature adults are more voracious feeders and resistant to pesticides than the callow adults (Koehler et al., 2011; Doug, 2009). \% FII of $A$. occidentale seed' alkaloids on the callow adult $R$. dominica $(\mathrm{P}$-value $=0.0140914)$ was higher than that on the mature adult $R$. dominica $(\mathrm{P}$-value $=0.024513)$. \% FII of $J$. curcas seed' alkaloids on callow adult $R$. dominica (P-value $=$ 0.002212 ) was also higher than that on the mature adult $R$. dominica $(\mathrm{P}$-value $=0.007682$ ). Thus the $J$. curcas seed' alkaloids had slightly higher feeding inhibitory indices compared to A. occidentale seed' alkaloids (tables 2 and 3). Growth rates of callow and mature adult insects that fed on maize treated with alkaloids were retarded, and consumption rates of maize reduced when compared with those of the controls (table 4). Hence the growth of callow and mature adult $R$. dominica is a function of consumption of maize. Prasad et al., 2012 reported that alkaloids in the seed, leaf and stem-bark extracts of $J$. curcas plant possessed antifeedant properties. Praveena et al., 2012 have also reported the antifeedant activity of $A$. occidentale seed oil to be concentration dependent.

\section{CONCLUSION}

Alkaloids from Jatropha curcas seeds exhibited slightly higher feeding inhibitory potentials than alkaloids from Anacardium occidentale seeds, which were later translated to slightly lower growth rates of both callow and mature adult insects at $400 \mu \mathrm{g} / \mathrm{mL}$ concentration. Therefore the Anacardium occidentale and Jatropha curcas seeds' alkaloids possess feeding inhibitory and growth retardatory potentials.

\section{RECOMMENDATION}

Further research works should be conducted to isolate specific alkaloidal compounds responsible for the feeding inhibitory and growth retardatory potentials of Anacardium occidentale and Jatropha curcas seeds' alkaloids on callow and mature adult $R$. domiica. Investigating these alkaloids to prove their non-toxic nature to mammalian cells will create an avenue for usage as protectants against Rhyzopertha dominica infestation of maize.

\section{ACKNOWLEDGEMENT}

The authors are thankful to authorities of Savannah Agricultural Research Institute (SARI), Nyankpala, Northern Region, Ghana for permitting the use of their laboratories to conduct this research.

\section{REFERENCES}

[1] Akash, P.D., Arun B. J.and Vishal D.J. (2009). Antimicrobial Screening of Different extracts of Anacardium occidentale Linn Leaves. International Journal of Chemical Technology Research 1(4) 856-858

[2] Azam-Ali and Judge, (2004). Small - scale Cashew Nut Processing. FAO, United Nations.

[3] Demissie A. G. and Lele S. S (2013). Bioactivity-Directed Isolation and Identification of Novel Alkaloid from Jatropha curcas (Linn). Research Journal of Chemical and Environmental Sciences, 1, 1-10.

[4] Doug, J. (2009).Insect Pests of Stored Grain; Lesser Grain Borer - Kenturky Extension, ENT FACT - 137. Department of Entomology, University of Kenturky.

[5] Ghodgate, A. G., Sawant, R. S., and Jadhav, S. D., (2013). Comparative Screening of Acetonic Extract of Fruits of 
Terminalia catappa Linn. and Anacardium occidentale Linn. Asian Journal of Plant Science and Research, 3(2), 150-153.

[6] Gupta, D. D.,Mahbub, H. A. K. M., Baigid, A. S., Hague, Md. E., Islam, Md N. and Shafigur R, (2011). Alkaloid and Steroid from Stem Bark of Jatropha curcas (Euphorbiceae). Dakhar University Journal of Pharmaceutical Sciences 10(1), 9-11.

[7] Ikbal, K. S. D., (2009). Evaluation of Genetic Diversity in Jatropha curcas L using RAPD markers. Indian Journal of Biotechnology, 9, 50-57.

[8] Jia, F., Toews, M.D., Campbell, J.F., Ramaswamy, S.B. (2008). Survival and Reproduction of Lesser Grain Borer, Rhyzopertha dominica (F.) (Coleoptera: Bostrichidae) on FloraAssociated withNative Habitats in Kansas. Journal of Stored Products Research 44, 366-372.

[9] Kannan, V.R., Sumathi, C.S., Balasubramanian, V., and Ramesh, N. (2009). Elementary Chemical Profiling and Antifungal Properties of Cashew (Anacardium occidentale L.) Nuts. Botany Research International, 2(4), 253-257.

[10] Koehler,P.G. and Pereira, R.M. (2011).Lesser Grain Borer, Rhyzopertha dominica F. (Coleoptera: Bostrichidae); IFAS Extension, ENY-264. University of Florida, 1-2.

[11] Mason, I.J. (2003). Grain Insect Fact Sheet E-238-W: Lesser Grain Borer, Rhyzopertha dominica (FaB.). Department of Entomology, Purdue University.

[12] Mishra, A, Tiwari, A., Yadav, M., Malakar, R. and Malviya, S. N. (2011). Estimation and Characterization of Protein Present in Seed Extract of Jatropha curcas. Journal of Advanced Research in Pharmaceuticals and Biologicals, 1(1), 1-10.

[13] Prasad, R. D. M., Amira, I., and Khan, Md. M. R., (2012). Jatropha curcas: Plant of Medicinal Benefits. Journal of Medicinal Plant Research, 6(14), 2691-2699.

[14] Praveena, R., Venkatasubbu, G.D. and Jegadeesan, M. (2012). Antifeedant Activity of Selected Medicinal Plants on Earias vitella. Journal of Biopesticides 5(2), 96-99.

[15] Toews, M.D., Campbel, J.F., Arthur, F.H. and Ramaswamy, S.B. (2006). Outdoor Flight Activity and Immigration of Rhyzopertha dominica into Seed Wheat Warehouses. Entomologia Experimentalis et Applicata 121:73-85 